\title{
EFFICIENCY OF GLYPHOSATE COMPLEXED WITH COPPER COMPARED TO THE COMMERCIAL PRODUCT IN Brachiaria decumbens Stapf
}

\author{
Soraia John da Silva1*, Tiago Franco dos Santos², Gabriela Guida ${ }^{3}$, Marcelo Hawrylak Herbst ${ }^{4}$, Sonia Regina \\ de Souza ${ }^{4}$, André Marques dos Santos ${ }^{4}$, Cristiane Martins Cardoso ${ }^{4}$
}

\begin{abstract}
'Discente de Pós-graduação em Química, Universidade Federal Rural do Rio de Janeiro, Unidade Seropédica, Seropédica-RJ
${ }^{2}$ Discente de Graduação em Agronomia, Universidade Federal Rural do Rio de Janeiro, Unidade Seropédica, Seropédica-RJ

${ }^{3}$ Discente de Graduação em Química Industrial, Universidade Federal Rural do Rio de Janeiro, Unidade Seropédica, Seropédica-RJ

${ }_{4}^{4}$ Professor Adjunto, Universidade Federal Rural do Rio de Janeiro, Unidade Seropédica, Seropédica-RJ

*Autor para correspondência: Soraia John da Silva, soraiajohndasilva@gmail.com
\end{abstract}

\begin{abstract}
Glyphosate, a non-selective herbicide with systemic action, is one of the most widely used substances in modern agriculture. With the objective of comparing the efficiency of glyphosate previously complexed with copper (Cu421) with that of the commercial product (Roundup WG®) and the purified substance (purified glyphosate) in controlling Brachiaria decumbens Stapf (signal grass), tests were conducted of the in vitro and in vivo activity of the enzymes 5-enolpyruvylshikimate-3-phosphate synthase (EPSPs) and phenylalanine ammonia lyase (PAL). The Cu421 complex significantly inhibited the EPSPs activity, as did the commercial product. In vivo test showed that treatments increased PAL activity more than double. The Cu421 complexed caused a substantial decline in the Falker chlorophyll index, as well as, the greatest reduction in the fresh mass yield and total protein concentration.

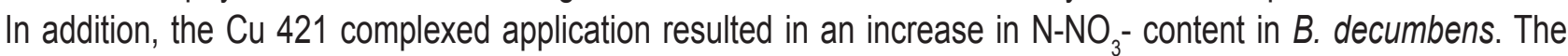
Cu421 complex had similar action as Roundup WG $\circledast$ and the purified glyphosate, indicating the possibility of using this complex to control weeds.
\end{abstract}

KEYWORDS: enzymes, EPSPs, herbicide, metal complex, PAL.

\section{EFICIÊNCIA DO GLIFOSATO COMPLEXADO COM COBRE COMPARADO AO PRODUTO COMERCIAL EM Brachiaria decumbens Stapf}

\section{RESUMO:}

O glifosato, um herbicida não seletivo de ação sistêmica, é uma das substâncias mais utilizadas na agricultura moderna. Com o objetivo de comparar a eficiência do glifosato previamente complexado com cobre (Cu421) com a do produto comercial (Roundup WG®) e a da substância purificada (glifosato purificado) no controle de Brachiaria decumbens Stapf (capim-braquiária), foram realizados ensaios in vitro e in vivo de atividade das enzimas 5-enolpiruvilchiquimato-3-fosfato sintase (EPSPs) e fenilalanina amônia liase (PAL). 0 complexo Cu421 inibiu significativamente a atividade de EPSPs, assim como o produto comercial. 0 ensaio in vivo mostrou que os tratamentos aumentaram a atividade de PAL mais que o dobro. O complexo Cu421 causou um declínio substancial no índice de clorofila Falker, bem como a maior redução no rendimento de massa fresca e concentração total de proteína. Além disso, a aplicação do complexo $\mathrm{Cu} 421$ resultou em um aumento no conteúdo de $\mathrm{N}_{-} \mathrm{NO}_{3}$ - em B. decumbens. 0 complexo Cu421 teve ação similar ao Roundup WG® e ao glifosato purificado, indicando a possibilidade de utilização deste complexo no controle de plantas daninhas.

PALAVRAS-CHAVE: enzimas, EPSPs, herbicida, complexo metálico, PAL.

\section{INTRODUCTION}

Chemical products are being increasingly used in modern agriculture, and according to Roustan et al. (2014), glyphosate is the world's leading herbicide in terms of sales. This product acts by inhibiting the enzyme 5-enolpyruvylshikimate-3-phosphate synthase (EPSPs), because it is an analog to the substrate of the enzyme, phosphenol pyruvate. EPSPs is the key enzyme in the synthesis pathway of the aromatic amino acids tryptophan, phenylalanine and tyrosine, 
which are essential to plant life. The symptoms caused by glyphosate in the plant are progressive yellowing of the leaves followed by necrosis (Rodrigues and Almeida, 2005).

Phenylalanine ammonia lyase (PAL) enzyme is responsible for converting phenylalanine into cinnamic acid (with release of ammonia), so it is directly involved in the process of producing phenolic compounds, besides being related to plants' defense system (Edagi et al., 2011). Marchiosi et al. (2009) reported an increase in the PAL activity after treatment of a susceptible soybean variety with glyphosate.

Despite the good efficacy of commercial products based on glyphosate, problems have been reported, in particular their toxicity to non-target species. This problem can be aggravated by the indiscriminate use of certain surfactants in these formulations. For example, one study indicated that the surfactant polyethoxylated tallow amine (POEA) is more toxic than glyphosate alone (Bradberry et al., 2004). Navarro and Martinez (2014) also observed toxic effects of this surfactant on fish.

Another problem caused using glyphosate is related to the fact it is a chelating agent. Therefore, glyphosate is naturally able to form complexes with various metals present in the soil. This complexation has been indicated as causing mineral deficiencies in the soil and reducing the herbicide's efficiency, as demonstrated by the studies of Wills and McWhorter (1985) and Bailey et al. (2002).

Other herbicides are also capable of complexing with soil metals, which may lead to the reducing bioavailability of these products. Due to this characteristic of the herbicides, several works were carried out on metal complexes - with emphasis on copper, as Drzewiecka - Antonik et al. (2017) and Sharma et al. (2017).

Although many studies present a synthesis of metal complexes of herbicides, there is a shortage of work comparing their effectiveness with commercial products.

This work, therefore, by objective, evaluated the efficacy of a glyphosate complex with divalent copper comparing it to purified and commercial glyphosate. Copper was chosen because of its great importance in plants and animals, as in the formation of metalloproteins (Lee, 1999) and because it is widely studied in complexation with glyphosate (Coutinho and Mazo, 2005).

To assess the efficiency of this complex with copper (Cu421 complex) in controlling weeds, comparative analyses were carried out of the effects of this compound, purified glyphosate and Roundup WG $\circledR$ (commercial product based on glyphosate) on the activity of the enzymes EPSPs and PAL, as well as on the chlorophyll index, fresh mass, $\mathrm{N}_{-} \mathrm{NO}_{3}$ - content and total protein concentration in $B$. decumbens Stapf plants. The goal was to determine whether the previously complexed compound can be effectively used as herbicide, minimizing the problems caused by use of purified glyphosate or its present commercial formulation.

\section{MATERIAL AND METHODS}

\section{Synthesis of the complex}

The glyphosate-copper complex was prepared according to the method described by Fonseca (2011). To prepare the complex with 2:1 stoichiometry (glyphosate:copper (II)), $400 \mathrm{mg}(2.36 \mathrm{mmol})$ of glyphosate was dissolved in $20 \mathrm{~mL}$ of water, after which the $\mathrm{pH}$ was adjusted to 4.0 by adding $6 \mathrm{~mol}$ $\mathrm{L}^{-1}$ of sodium hydroxide, followed by addition of the copper nitrate solution (II). The reaction was kept under stirring for 3 hours and then the solution was washed in a rotary evaporator for partial removal of the solvent. Ethyl alcohol was added to the resulting concentrated solution, which was kept in a refrigerator for several days, until the occurrence of precipitation. The supernatant was removed and the solid was washed with ethanol and placed in an oven at $80^{\circ} \mathrm{C}$ for drying. The product obtained (blue powder soluble in water) had yield above $90 \%$. The complex was called Cu421 due to its $\mathrm{pH}$ and stoichiometry, respectively.

\section{Determination of the protein concentration}

$B$. decumbens leaves were macerated in liquid nitrogen and homogenized in the buffer HEPES 57 mM pH 7.0 (1:4 weight/volume). Then each sample was centrifuged at $1,500 \mathrm{rpm}$ for $15 \mathrm{~min}$ at $2{ }^{\circ} \mathrm{C}$ and diluted 5 -fold. The supernatant was stored at $-80^{\circ} \mathrm{C}$. The protein concentration was determined by the method of Peterson (1977), obtaining a total protein concentration of $2.93 \mathrm{mg} \mathrm{mL}^{-1}$ in the samples used in the in vitro assay. 


\section{Determination of the EPSPs activity}

The EPSPs activity was measured by quantification of the inorganic phosphate (Itaya and $\mathrm{Ui}$, 1966) released during transfer of the enolpyruvyl group from phosphenol pyruvate (PEP) to shikimato3-phosphate (S3P), following the method proposed by Forlani et al. (1994) and Gonçalves et al. (2002), with adaptations. In the reaction medium, $10 \mu \mathrm{L}$ each of S3P and PEP (both $5 \mathrm{mM}$ ) were added to a plant sample volume corresponding to $0.03 \mathrm{mg}$ of protein, after which a sufficient volume of the buffer HEPES $57 \mathrm{mM} \mathrm{pH} 7.0$ was added to complete $50 \mu \mathrm{L}$ of reaction volume. After incubation for 30 minutes at $37^{\circ} \mathrm{C}$, the reaction was stopped by adding $250 \mu \mathrm{L}$ of a color reagent $(0.2 \%$ malachite green and $4.2 \%$ ammonium molybdate) in hydrochloric acid $5 \mathrm{~N}$ in 3:1 proportion, respectively and $75 \mu \mathrm{L}$ of $1.5 \%$ Tween 20 . The absorbance was measured at $655 \mathrm{~nm}$. Blanks were also analyzed without adding S3P and PEP. The enzyme activity was determined by using the linear equation obtained from the standard curve of phosphate. The molar absorption coefficient under these conditions is $75,000 \mathrm{M}^{-1} \mathrm{~cm}^{1}$.

The analysis of the in vitro effect of Roundup WG, purified glyphosate and Cu421 complex on EPSP activity was performed on samples of $B$. decumbens not previously treated with glyphosate. In this way, enough of these compounds were added to give a final concentration of $0.5 \mathrm{mM}$ thereof. Subsequently, the same procedure was followed for the in vivo assay.

\section{Determination of the PAL activity}

The PAL activity was estimated based on the difference of absorbances resulting from the conversion of phenylalanine into trans-cinnamic acid, following the method proposed by Barreto and Neto (2011) with some modifications.

In $1 \mathrm{~mL}$ of reaction medium, a volume of plant sample corresponding to $1 \mathrm{mg}$ of protein was added, followed by the buffer Tris $0.5 \mathrm{M} \mathrm{pH} 8.5$ and $160 \mu \mathrm{L}$ of phenylalanine $300 \mu \mathrm{M}$. After incubation for 30 minutes at $40^{\circ} \mathrm{C}$, the reaction was stopped by immersion in an ice bath for 5 minutes. The absorbance was measured at $290 \mathrm{~nm}$. Blanks were also analyzed by adding distilled water instead of phenylalanine. All the enzyme tests were performed in duplicate.

The enzyme activity was determined by using the molar absorbance coefficient $104 \mathrm{mM}^{-1} \mathrm{~cm}^{-1}$ (Zucker,
1965).

The analysis of the in vitro effect of Roundup WG, purified glyphosate and Cu421 complex on PAL activity was performed on samples of $B$. decumbens not previously treated with glyphosate. In this way, enough of these compounds were added to give a final concentration of $0.5 \mathrm{mM}$ thereof. Subsequently, the same procedure was followed for the in vivo assay.

\section{Analysis of the presence of nitrate in the Cu421 complex}

The presence of nitrate in the Cu421 complex was analyzed by the method proposed by Miranda et al. (2001), which is based on the conversion of nitrate into nitrite. For this purpose, were used solutions of $\mathrm{N}$-naphthyl ethylenediamine $(0.02 \%)$, sulfanilamide $(0.4 \%)$ in $\mathrm{HCl} 1 \mathrm{M}$ and vanadium chloride $(0.5 \%)$ in $\mathrm{HCl}$ $1 \mathrm{M}$, mixed at a proportion of $1: 1: 2$, respectively, at the moment of analysis.

In the reaction medium, $30 \mu \mathrm{L}$ of Cu 421 at $6.6 \%$ (based on the concentration used in the field) and $60 \mu \mathrm{L}$ of the mixture of reagents described above were added. The reaction was incubated at $40{ }^{\circ} \mathrm{C}$ for 50 minutes, after which $100 \mu \mathrm{L}$ of Milli-Q water was added, and the solution was read by spectrophotometry at $540 \mathrm{~nm}$. The nitrate concentration in the complex was determined by using the linear equation obtained from the standard curve of nitrate. The test was performed in duplicate.

\section{Greenhouse experiment}

Brachiaria decumbens Stapf plants were grown in a greenhouse with four treatments: Control (without glyphosate), Roundup WG® (commercial glyphosate), Glyphosate (purified glyphosate) and Cu421 Complex. The experiment was carried out with four replicates in a completely randomized design, for a total of 16 experimental units (pots). It was necessary to reduce the experimental unit numbers due to the low yield in the complex with $\mathrm{Cu}$ synthesis. The treatments were applied 30 days after germination, using manual sprayers, following the recommendations for application of the commercial product $\left(2.5 \mathrm{~kg} \mathrm{ha}^{-1}\right.$ of the commercial product, equivalent to $2 \mathrm{~kg}$ of a.i. ha $^{-1}$ ) [active ingredient per hectare]. After application of the treatments, the Falker chlorophyll index (FCl) was measured daily, using a clorofiLOG CFL1030 chlorophyll meter (Falker Automação Agrícola, Brazil). 
The fresh mass accumulation was determined on the ninth day after applying the treatments and $1 \mathrm{~g}$ of fresh aerial part material was collected from each plant for total protein measurement and the enzyme tests, and $1 \mathrm{~g}$ for alcohol extraction followed by partition with chloroform (Fernandes, 1984). The soluble fraction was stored and subsequently used to determine the N-NO3concentrations (Cataldo et al., 1975).

\section{Statistical analysis}

The results were analyzed by ANOVA and the averages were compared by the Tukey test with confidence limit of 95\%, using SISVAR for Windows version 5.3 (Ferreira, 2011).

\section{RESULTS AND DISCUSSION}

\section{Enzyme activities in $B$. decumbens}

The average activity values obtained for the control group in the in vitro tests (Figure $1 \mathrm{~A}$ and Figure 1B) were $2.34 \mathrm{nmoL} \mathrm{min} \mathrm{mg}^{-1}$ of protein for EPSPs and $2.67 \mathrm{nmoL} \mathrm{min}^{-1} \mathrm{mg} 1$ of protein for PAL.

Figure 1. Effect of the treatments on Brachiaria decumbens. CTR: Control (without glyphosate); GLY: Glyphosate (purified glyphosate); WG: Roundup WG® (commercial glyphosate); Cu421: Cu421 Complex (Cu421, glyphosate previously complexed with copper). (A) In vitro test of EPSPs. (B) In vitro test of PAL. (C) In vivo test of EPSPs. (D) In vivo test of PAL. (E) Falker chlorophyll index ( $\mathrm{FCl})$. The bars represent the mean \pm standard deviation of four replicates. Tukey test $(\alpha=0,05)$.
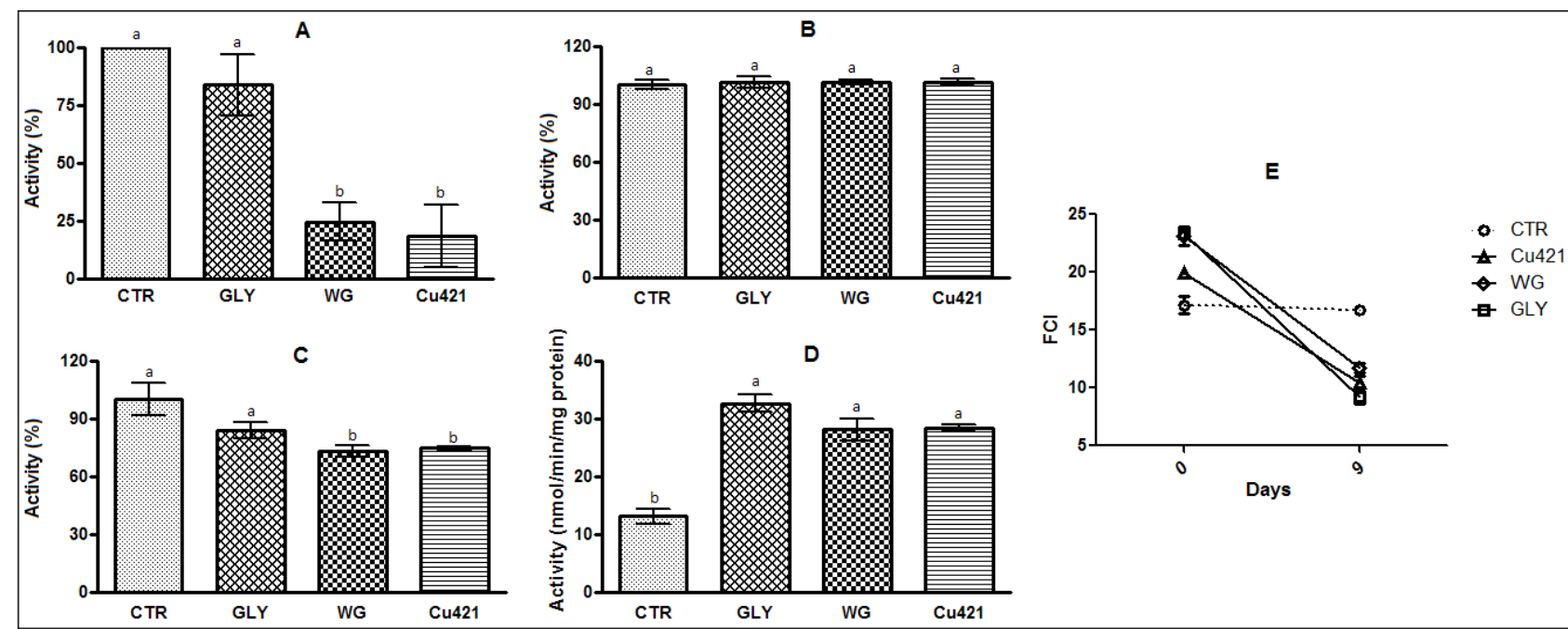

As can be observed in Figure $1 \mathrm{~A}$, the copper complex (Cu421) and Roundup WG® significantly inhibited the EPSPs activity in vitro. In contrast, purified glyphosate did not significantly inhibit the enzyme activity in either the in vitro (Figure $1 \mathrm{~A}$ ) or in vivo assay (Figure 1C). According to Wills and McWhorter (1985), cations addition may increase, reduce or not influence the herbicidal effect of glyphosate. An increase or decrease in efficacy may be related to our product absorption and translocation processes.

As expected, Roundup WG ${ }^{\circledR}$ was more effective in both tests of EPSPs activity in relation to its main active ingredient alone (purified glyphosate) corroborating the hypothesis that another compound in the commercial formulation enhances the glyphosate effect, through a synergistic process. This mechanism occurs when the combination of two compounds has a stronger effect than either one alone. In the case here, we believe that the combination of glyphosate with the ammonium salt present in Roundup WG®, as well as with copper in complex, makes the inhibition of the EPSPs activity more pronounced. In the study by Carvalho et al. (2008), the ammonium sulfate addition to the glyphosate solution increased the control of weeds in the field for concentrations up to $10 \mathrm{~g} \mathrm{~L}^{-1}$, which strengthens this hypothesis.

In the in vivo test of EPSPs, the average activity value in the control group was $2.89 \mathrm{nmoL} \mathrm{min}{ }^{-1} \mathrm{mg}^{-1}$ of protein and the average inhibition percentages of the compounds were $25.48 \%$ for Cu421 and $26.86 \%$ for 
Roundup WG®. Since EPSPs is the target enzyme of glyphosate, its inhibition was expected. Marchiosi et al. (2009) also observed a similar result when analyzing the glyphosate effect on the shikimate accumulation in a glyphosate-susceptible culture, finding that this accumulation was the result of EPSPs inhibition.

As can be seen in Figure 1B, the PAL activity in $B$. decumbens was not influenced by the treatments. The non-significant in vitro effects of the treatments on this enzyme's activity demonstrate that glyphosate is unable to directly activate PAL.

In the in vivo experiment, the inductive effect of glyphosate-based treatments on the PAL activity was observed. All the treatments increased PAL activity significantly (Figure 1D). The average of PAL activity in the control group was $13.1 \mathrm{nmoL} \mathrm{min}{ }^{-1} \mathrm{mg}^{-1}$ of protein and all the treatments increased this activity, by approximately 2.3 times.

The increase in the PAL activity when applying glyphosate and the Cu421 complex was expected, since similar results have been reported by various researchers, such as Marchiosi et al. (2009) and Hoagland (1990), investigating the effect of this herbicide on the PAL activity in others plant species. According to Silva et al. (2009), glyphosate, by inhibiting EPSPs, prevents the secondary metabolites formation and at the same time stimulates the PAL activity, promoting an increase in the phenolic compounds synthesis.

The increase in the PAL activity can be due to the plant's secondary metabolism reduction caused by the inhibition of EPSPs, or even as a plant defense form.

Table 1. Fresh mass, N-NO3- levels and protein concentration in the aerial part of Brachiaria decumbens nine days after treatments application.a

\begin{tabular}{cccc}
\hline Treatments & $\begin{array}{c}\text { Fresh mass } \\
\left(\mathrm{g} \mathrm{pots}^{-1}\right)\end{array}$ & $\begin{array}{c}\mathrm{N}-\mathrm{NO}_{3}^{-} \\
\left(\mu \mathrm{mol} \mathrm{gmf} \mathrm{gm}^{-1}\right)\end{array}$ & $\begin{array}{c}\text { Protein concentration } \\
\left(\mathrm{mg} \mathrm{mL}^{-1}\right)\end{array}$ \\
\hline CTR & $1.47 \mathrm{a}$ & $58.90 \mathrm{~b}$ & $4.87 \mathrm{a}$ \\
Cu421 & $0.43 \mathrm{~d}$ & $144.66 \mathrm{a}$ & $1.10 \mathrm{~d}$ \\
WG & $0.60 \mathrm{bc}$ & $61.75 \mathrm{~b}$ & $2.16 \mathrm{c}$ \\
GLY & $0.63 \mathrm{bc}$ & $62.97 \mathrm{~b}$ & $4.54 \mathrm{~b}$ \\
\hline CV (\%) & 27.47 & 6.45 & 1.92 \\
\hline
\end{tabular}

aTreatments: CTR: Control (without glyphosate); Cu421: Cu421 Complex (Cu421, glyphosate previously complexed with copper); WG: Roundup WG® (commercial glyphosate); GLY: Glyphosate (purified glyphosate). Means within a column followed by the same letter are not significantly different at the $5 \%$ level as determined by Tukey test. Values are means of four replicates.

\section{Falker chlorophyll index, fresh mass yield and $\mathrm{N}-\mathrm{NO}_{3}$ - content}

In the greenhouse experiment, the Falker chlorophyll index $(\mathrm{FCl})$ was measured on the first day (day 0) and last day (day 9). The results are shown in Figure 1.

Comparison of the change in $\mathrm{FCl}$ values obtained for the treated plants between the last and first day of the experiment with the corresponding values for the control group revealed that all three treatments (Roundup WG®, copper complex and purified glyphosate) caused a substantial decline in the index. Purified glyphosate caused an average decrease of 14.1, while these declines were 11.4 for Roundup WG® and 9.4 for the copper complex. Hoagland (1980) also observed a reduction in the total chlorophyll content in plants treated with glyphosate. Similarly, Zobiole et al. (2012) demonstrated the ability of glyphosate to inhibit the photosynthesis rate. Brighenti et al. (2011) also reported a negative effect of glyphosate on the chlorophyll content.

All the compounds analyzed in this study also caused alteration in the fresh mass yield, but only the copper complex had a significant influence on the N-NO3- level in the aerial part of $B$. decumbens (Table I). 
As shown in Table I, the copper complex caused the greatest reduction of fresh mass (decline of $1.04 \mathrm{~g}$ in relation to the control plants), and caused an increase in of $85.7 \mu \mathrm{mol}$ gmf1 in the soluble nitrate content in the aerial part of $B$. decumbens. This increase might be due to the inhibition of the nitrate reductase activity. Another possibility is that the increase of nitrate content in aerial part could be due the residual nitrate presence in the complex, since copper nitrate was used to prepare this compound. Future tests should be conducted to determine the nitrate reductase activity under these conditions, to prove or disprove this hypothesis.

\section{Presence of nitrate in the Cu421 complex}

The hypothesis that the presence of residual nitrate from synthesis of the Cu421 complex influenced the soluble nitrate levels in the aerial part of $B$. decumbens was investigated by measuring the nitrate levels in this complex's solution, as described previously in the methodology.

The results found were $74 \mathrm{ng}$ of nitrate in $2 \mathrm{mg}$ of Cu421 complex. Although this is a small quantity, its presence can interfere in the plant's metabolism, as observed by the increase in the N-NO3- concentration in the grass treated with this complex. It should be mentioned that the presence of this nitrogen source can be advantageous to species resistant to glyphosate cultivated together with weeds targeted for control.

\section{Protein levels analysis in $B$. decumbens}

The three treatments also significantly influenced the total protein concentration in the $B$. decumbens leaves (Table I).

As shown in Table I, the copper complex was the compound that caused the largest decrease in the total protein concentration (drop of $3.77 \mathrm{mg} \mathrm{mL}-1$ ). This reduction can be a consequence of the aromatic amino acids biosynthesis blocking due to the inhibitory action of glyphosate on the formation of the precursor (EPSP). This blockage, according to Bervald et al. (2010), reduces the soluble proteins levels in plant tissues.

It was possible to conclude from this study that the copper complex (Cu421) has potential for use as herbicide, because it significantly inhibited the activity of the target enzyme (EPSPs), negatively affecting the fresh mass, the protein concentration and the Falker chlorophyll index, and consequently, reducing the vegetative growth of Brachiaria decumbens.

\section{ACKNOWLEDGMENTS}

The authors are grateful to Research Support Foundation of the State of Rio de Janeiro (FAPERJ) for the financial support and the National Council for the Improvement of Higher Education (CAPES) for the scholarship.

\section{ACKNOWLEDGMENTS}

We are especially grateful to Dr. Sônia Regina de Souza (in memorian) for contributions made to biochemistry and for all her teachings.

\section{REFERENCES}

Bailey, W.A.; Poston, D.H.; Wilson, H.P.; Hines, T.E. Glyphosate Interactions with Manganese. Weed Technology. 2002, 16, 792-799.

Barreto, L.; Neto, E. Análises Químicas e Bioquímicas em Plantas. EDU - Editora Universitária da UFRPE: Pernambuco, 2011; 261p.

Bervald, C.M.P.; Mendes, C.R.; Timm, F.C.; Moraes, D.M.; Barrros, A.C.S.A.; Peske, S.T. Desempenho fisiológico de sementes de soja de cultivares convencional e transgênica submetidas ao glifosato. Revista Brasileira de Sementes. 2010, $32,09-18$.

Bradberry, S.M.; Proudfoot, A.T.; Vale, J.A. Glyphosate Poisoning. Toxicological Reviews. 2004, 23, 159-167.

Brighenti, A.M.; Sobrinho, F.D.S.; Rocha, W.S.D.; Martins, C.E.; Dermatini, D.; Costa, T.R. Suscetibilidade diferencial de espécies de braquiária ao herbicida glifosato. Pesquisa Agropecuária Brasileira. 2011, 46, 1241-1246.

Carvalho, S.J.P.; Dias, A.C.R.; Damin, V.; Nicolai, M.; Christoffoleti, P.J. Glifosato aplicado com diferentes concentrações de uréia ou sulfato de amônio para dessecação de plantas daninhas. Pesquisa Agropecuária Brasileira. 2008, 43, 1501-1508.

Cataldo, D.A.; Maroon, M.; Schrader, L.E.; Youngs, V.L. Rapid colorimetric determination of nitrate in plant tissue by nitration of salicylic acid. Communications in Soil Science ans Plant Analysis. 1975, 6, 71-80. 
Coutinho, C.F.B.; Mazo, L.H. Complexos metálicos com o herbicida glifosato: revisão. Química Nova. 2005, 28 , 6.

Drzewiecka-Antonik, A.; Ferenc, W.; Wolska, A.; Klepka, M.; Cristovao, B.; Sarzynsk, J.; Rejmak, J.; Ospiuk, D. The $\mathrm{Co}(\mathrm{II}), \mathrm{Ni}(\mathrm{II})$ and $\mathrm{Cu}(\mathrm{II})$ complexes with herbicide 2,4-dichlorophenoxyacetic acid - Synthesis and structural studies. Chemical Physics Letters. 2017, 667, 192-198.

Edagi, F.K.; Sestari, I.; Sasaki, F.F.; Terra, F.A.M.; Kluge, R.A. Compostos salicilados e tolerância de nêsperas ao frio. Pesquisa Agropecuária Brasileira. 2011, 46, 562-565.

Fernandes, M.S. N-carriers, light and temperature influences on uptake and assimilation of nitrogen by rice. Turrialba. 1984, 34, 9-18.

Ferreira, D.F. SISVAR : A Computer statistical analysis system. Ciência e Agrotecnologia. 2011, 35, 1039 1042.

Fonseca, N.F. Contribuição ao estudo da complexação do glifosato com cátions divalentes de metais da primeira série de transição. Universidade Federal Rural do Rio de Janeiro. 2011.

Forlani, G.; Parisi, B.; Nielsen, E. 5-enol-PyruvylShikimate-3-Phosphate Synthase from Zea mays Cultured Cells (Purification and Properties). Plant Physiology. 1994, 105, 1107-1114.

Gonçalves, A.H.; Silva, J.B.; Souza, I.F.; Purcino, A.A.C. Subdoses de sulfosate sobre a inibição da atividade da EPSPS em plantas de milho. Planta Daninha. 2002, 20, 465-470.

Hoagland, R.E. Effects of Glyphosate on Metabolism of Phenolic Compounds: VI. Effects of Glyphosine and Glyphosate Metabolites on Phenylalanine AmmoniaLyase Activity, Growth, and Protein, Chlorophyll, and Anthocyanin Levels in Soybean (Glycine max) Seedlings. Weed Science. 1980, 28, 393-400.

Hoagland, R.E. Interaction of indoleacetic acid and glyphosate on phenolic metabolism in soybeans. Pesticide Biochemistry and Physiology. 1990, 36, 68-75.
Itaya, K.; Ui, M. A new micromethod for the colorimetric determination of inorganic phosphate. Clinica Chimica Acta. 1966, 14, 361-366.

Lee, J.D. Química Inorgânica Não Tão Concisa, 5a edição. Edgard Blücher Ltda: São Paulo, SP, 1999; 527 p.

Marchiosi, R.; Ferrarese, M.D.L.; Bonini, E.A.; Fernandes, N.G.; Ferro, A.P.; Ferrarese-filho, 0. Glyphosate-induced metabolic changes in susceptible and glyphosate-resistant soybean (Glycine max L.) roots. Pesticide Biochemistry and Physiology. 2009, 93, 28-33.

Miranda, K.M.; Espey, M.G.; Wink, D.A. A rapid, simple spectrophotometric method for simultaneous detection of nitrate and nitrite. Nitric Oxide. 2001, 5, 62-71.

Navarro, C.D.C.; Martinez, C.B.R. Effects of the surfactant polyoxyethylene amine (POEA) on genotoxic, biochemical and physiological parameters of the freshwater teleost Prochilodus lineatus. Comp. Biochem. Physiol. Part C Toxicol. Pharmacol. 2014, 165, 83-90.

Peterson, G.L. A simplification of the protein assay method of Lowry et al. which is more generally applicable. Analytical Biochemistry. 1977, 83, 346-356.

Rodrigues, B.N.; Almeida, F.S. Guia de herbicidas, Londrina, 2005; 592 p.

Roustan, A.; Aye, M.; Meo, M.; Giorgio, C.D.I. Genotoxicity of mixtures of glyphosate and atrazine and their environmental transformation products before and after photoactivation. Chemosphere. 2014, 108, 93-100.

Sharma, R.P.; Saini, A.; Kumar, J.; Kumar, S.; Venugopalan, P.; Ferretti, V. Coordination complexes of copper (II) with herbicide-trichlorophenoxyacetate: Syntheses, characterization, single crystal X-ray structure and packing analyses of monomeric [Cu (v-pic) 3 (2, 4, 5-trichlorophenoxyacetate)] $\mathrm{H} 2 \mathrm{O}$, [trans$\mathrm{Cu}$ (en) 2 (2, 4, 5-trichlorophenoxyacetate) 2] $2 \mathrm{H} 2 \mathrm{O}$ and dimeric [Cu2 (H2tea) 2 (2, 4, 5-trichlorophenoxyacetate) 2] 2 (H2O). Inorganica Chimica Acta. 2017, 457, 59-68. 
Silva, M.D.A., Aragão, N.C.; Barbosa, M.A.; Jeronimo, Z Zobiole, L.H.S.; Kremer, R.J.; Oliveira Junior, R.S.; E.M.; Carlin, S.D. Efeito hormótico de gliphosate no Constantin, J. Glyphosate effects on photosynthesis, desenvolvimento inicial de cana-de-açúcar. Bragantia. nutrient accumulation, and nodulation in glyphosate2009, 68, 973-978. resistant soybean. Plant Nutrition and Soil Science Journal. 2012, 175, 319-330.

Wills, G.D.; Mcwhorter, C.G. Effect of inorganic salts on the toxicity and translocation of glyphosate and MSMA in purple nutsedge (Cyperus rotundus). Weed Science. 1985, 33, 755-761.

Zucker, M. Induction of Phenylalanine Deaminase by Light and its Relation to Chlorogenic Acid Synthesis in Potato Tuber Tissue. Plant Physiology. 1965, 40, 779-784. 